\title{
Effect of Alloying Elements on the Mechanical Properties of the Stable Austenitic Stainless Steel
}

\author{
Naoto OHKUBO, Katsuhisa MIYAKUSU, Yoshihiro UEMATSU and Hiroshi KIMURA ${ }^{1)}$
}

Stainless Steel \& High Alloy Department, Steel R \& D Laboratories, Nisshin Steel Co., Ltd., Nomuraminami-machi, Shin-nanyo, Yamaguchi-ken, 746 Japan. Marunouchi, Chiyoda-ku, Tokyo, 100 Japan.

(Received on April 18, 1994; accepted in final form on June 24, 1994)

The effects of various alloying elements on the mechanical properties of stable austenitic stainless steel have been investigated in order to soften it. Results obtained are as follows:

(1) Experimental equations are proposed, which give the hardness $(H V), 0.2 \%$ proof stress $\left(\sigma_{0.2}\right)$ and tensile strength $\left(\sigma_{B}\right)$ as functions of the chemical composition.

(2) Reduction of $\mathrm{C}, \mathrm{N}, \mathrm{Si}, \mathrm{Cr}$ and $\mathrm{Mo}$ and addition of $\mathrm{Ni}, \mathrm{Cu}$ and $\mathrm{Mn}$ are effective to decrease the hardness, $0.2 \%$ proof stress and tensile strength.

(3) $\sigma_{0.2}$ is increased by the addition of alloying elements which cause lattice strains, i.e., C, N and Mo. The larger the lattice strain, the larger the increase in $\sigma_{0.2} .0 .2 \%$ proof stress is decreased by the addition of $\mathrm{Ni}, \mathrm{Cu}$ and $\mathrm{Mn}$, which increase the stacking fault energy (SFE), although these elements cause slight lattice strains. Addition of $\mathrm{Si}$, which reduces $\mathrm{SFE}$, increases $\sigma_{0.2}$.

(4) The dislocation structures are essentially cell-structures, except for $\mathrm{N}$-added steels. The cell size is varied with alloying elements through the change in SFE.

(5) The work hardening rate is reduced by $\mathrm{Ni}, \mathrm{Cu}$ and $\mathrm{Mn}$, which have been reported to increase SFE and hence are considered to activate cross-slip. On the other hand, a SFE-reducing element, Si, increases the work hardening rate. The addition of $\mathrm{N}$, another SFE-reducing element, however, decreases work hardening rate. This effect may result from the difficulty in forming the cell-structure in the $\mathrm{N}$-added steel in contrast with the Si-added steel.

KEY WORDS: stable austenitic stainless steel; hardness; tensile properties; solid-solution; work hardening; stacking fault energy; sub-structure.

\section{Introduction}

Austenitic stainless steels, such as SUS 304, are widely used owing to their superior corrosion resistance and workability. However, because of their relatively high hardness compared to low carbon Al-killed steel sheets, it is sometimes difficult to assure enough formability of cold-rolled and annealed austenitic stainless steel sheets. Production of softer stainless steel sheets will surely expand the use of these stainless steels. Aiming at this goal, we have investigated the effects of alloying elements on the mechanical properties of austenitic stainless steels.

The formability of austenitic stainless steels varies according to the type of steels. For example, metastable phase steels such as SUS 304 of $18 \mathrm{Cr}-8 \mathrm{Ni}$ tend to induce the martensite by deformation. On the other hand, stable steels such as SUS 305 of $18 \mathrm{Cr}-11 \mathrm{Ni}$ are hardly do so. For metastable steels, the effect of alloying on the stability of the austenite phase against deformation have been widely studied with respect to the transformationinduced plasticity and formability. ${ }^{1-5)}$ For stable steels, the effects of alloying elements on hardness and tensile properties have been studied by Irvine et al. ${ }^{6}$ and Dyson and Holms ${ }^{7)}$ with respect to the solid-solution hardening. The work hardening in stable steels is known to be related to the stacking fault energy (SFE), ${ }^{8)}$ and the effect of alloying elements on SFE has been studied in detail. ${ }^{9-12)}$ Considering the relation between SFE and work hardening rate, Ueki et al. ${ }^{13)}$ have reported the effects of $\mathrm{Ni}$ and $\mathrm{Cr}$ on the tensile properties of stable austenitic stainless steels. However, effects of other alloying elements on the hardness and tensile properties have not been studied in view of SFE so far.

In the present research, the effects of various alloying elements on the mechanical properties are investigated in order to develop softer austenitic stainless steels. The results are discussed in terms of SFE and the dislocation structure.

\section{Materials and Experimental Methods}

\subsection{Materials}

The chemical compositions of materials used in the 
Table 1. Chemical compositions of investigated materials.

\begin{tabular}{|c|c|c|c|c|c|c|c|c|c|c|}
\hline Sample No. & $\mathrm{C}$ & $\mathrm{Si}$ & $\mathrm{Mn}$ & $\mathrm{P}$ & $\mathrm{S}$ & $\mathrm{Ni}$ & $\mathrm{Cr}$ & $\mathrm{Mo}$ & $\mathrm{Cu}$ & $\mathrm{N}$ \\
\hline $\mathrm{A} 1$ & 0.003 & 0.09 & 0.80 & 0.026 & 0.001 & 11.87 & 16.98 & - & - & 0.003 \\
\hline $\mathrm{A} 2$ & 0.010 & 0.08 & 0.77 & 0.029 & 0.001 & 12.00 & 16.92 & - & - & 0.005 \\
\hline $\mathrm{A} 3$ & 0.031 & 0.11 & 0.81 & 0.024 & 0.001 & 11.83 & 16.74 & - & - & 0.002 \\
\hline $\mathrm{A} 4$ & 0.004 & 0.09 & 0.78 & 0.022 & 0.001 & 11.96 & 16.85 & - & - & 0.028 \\
\hline A5 & 0.005 & 0.10 & 0.61 & 0.023 & 0.001 & 11.98 & 16.80 & - & - & 0.041 \\
\hline $\mathrm{A} 6$ & 0.004 & 0.80 & 0.80 & 0.025 & 0.001 & 11.82 & 17.04 & - & - & 0.002 \\
\hline $\mathrm{A} 7$ & 0.003 & 0.10 & 2.01 & 0.025 & 0.001 & 11.81 & 16.96 & - & - & 0.006 \\
\hline A8 & 0.003 & 0.12 & 2.91 & 0.016 & 0.001 & 11.66 & 16.87 & - & - & 0.002 \\
\hline A.9 & 0.005 & 0.10 & 0.79 & 0.025 & 0.001 & 9.91 & 16.80 & - & - & 0.002 \\
\hline A10 & 0.004 & 0.09 & 0.76 & 0.026 & 0.001 & 12.53 & 16.88 & - & - & 0.003 \\
\hline A11 & 0.004 & 0.10 & 0.79 & 0.022 & 0.001 & 13.71 & 16.76 & - & - & 0.003 \\
\hline A12 & 0.003 & 0.09 & 0.76 & 0.024 & 0.001 & 12.03 & 17.80 & - & - & 0.004 \\
\hline A13 & 0.001 & 0.10 & 0.77 & 0.025 & 0.001 & 11.72 & 16.71 & 0.50 & - & 0.005 \\
\hline A14 & 0.002 & 0.12 & 0.76 & 0.028 & 0.002 & 11.77 & 16.78 & 1.51 & - & 0.004 \\
\hline A15 & 0.004 & 0.10 & 0.78 & 0.022 & 0.001 & 11.84 & 16.76 & - & 0.91 & 0.002 \\
\hline A16 & 0.007 & 0.09 & 0.78 & 0.024 & 0.001 & 11.77 & 16.90 & - & 2.84 & 0.003 \\
\hline A17 & 0.004 & 0.11 & 0.77 & 0.024 & 0.001 & 11.81 & 16.86 & - & 3.99 & 0.003 \\
\hline
\end{tabular}

present experiment are shown in Table 1. The base steel $\mathrm{Al}$ is $17 \mathrm{Cr}-12 \mathrm{Ni}-0.8 \mathrm{Mn}$ steel containing low concentration of $\mathrm{C}, \mathrm{N}$ and $\mathrm{Si}$. In order to investigate the effect of alloying elements on solid solution hardening, steels denoted A2, A3, A4, A5, A13 and A14 were prepared, in which the concentration of interstitial elements $\mathrm{C}$ $(0.003-0.031$ mass $\%)$ and $N(0.003-0.041$ mass $\%)$ and of a substitutional element Mo (0-1.51 mass\%) were varied. To investigate the effect on work hardening, steels A6 to A12 and A15 to A17 were prepared in which variations were made in the contents of $\mathrm{Si}(0.09-0.80$ mass \%), Mn (0.80-2.91 mass\%), Ni (9.91-13.71 mass\%), $\mathrm{Cr}(11.87-17.80$ mass\%) and $\mathrm{Cu}(0-3.99$ mass\%). These elements change SFE.

The procedure of material preparation is shown in Fig. 1. These materials were melted in high frequency induction furnace of $12 \mathrm{~kg}$ capacity under a vaccum and cast in the Argon atmosphere. The ingots were forged at $1250^{\circ} \mathrm{C}$ to $25 \mathrm{~mm}$ thickness, reheated to $1220^{\circ} \mathrm{C}$ and hot-rolled to $3.8 \mathrm{~mm}$ thickness. The hot-rolled bands were annealed at $1150^{\circ} \mathrm{C}$ for $1 \mathrm{~min}$. They were cold-rolled to $1.4 \mathrm{~mm}$ thickness and again annealed at $1050^{\circ} \mathrm{C}$ for $1 \mathrm{~min}$, and finally cold-rolled to $0.7 \mathrm{~mm}$ thickness. Since the mechanical properties depend on the grain size, specimens were annealed at various temperatures ( 950 to $1150^{\circ} \mathrm{C}$ ) for $1 \mathrm{~min}$ to obtain various grain sizes, and the mechanical properties were investigated in relation to the grain size.

\subsection{Methods of Measurements}

The hardness $(H V)$ was measured by a Vickers hardness testing machine with $10 \mathrm{~kg}$ load. The dimension of tensile specimens was $50 \mathrm{~mm}$ in gauge length with

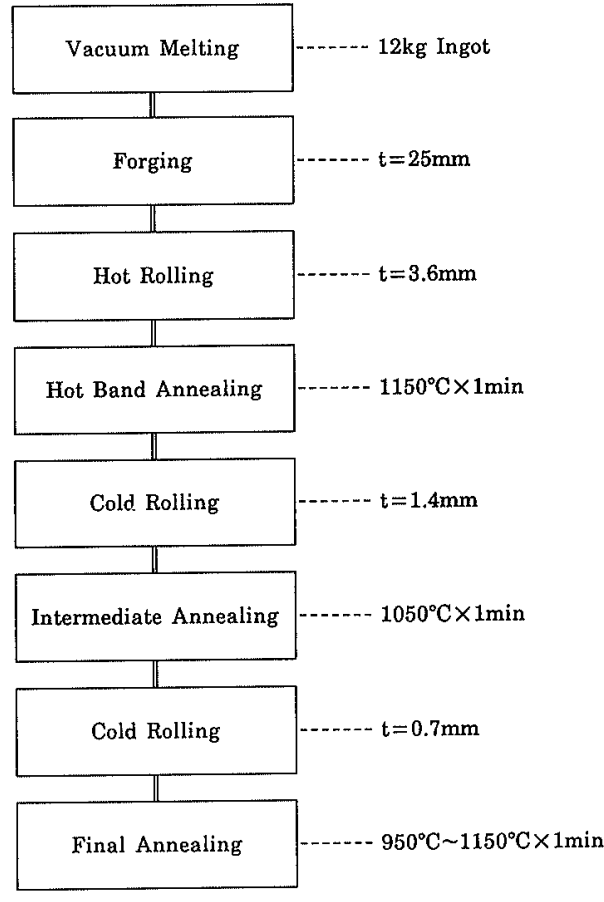

Fig. 1. Preparation procedure of materials.

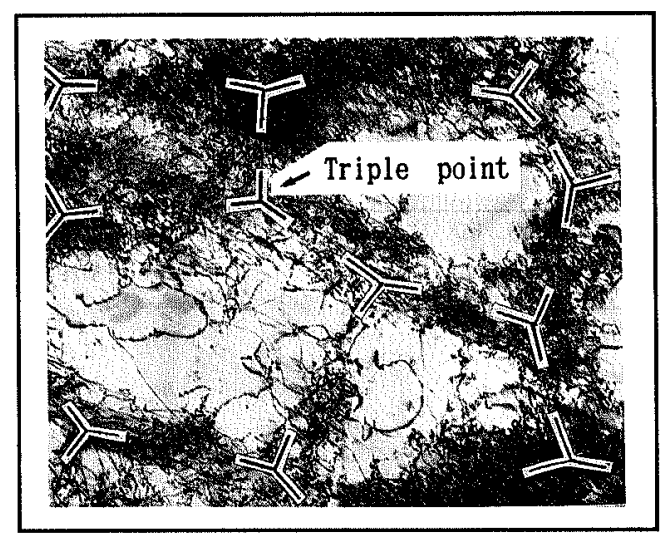

Fig. 2. An example of cell structure.

width of $12.5 \mathrm{~mm}$ (JIS 13B specimen). The $0.2 \%$ proof stress $\left(\sigma_{0.2}\right)$ and tensile stress $\left(\sigma_{B}\right)$ were measured with an Instron-type tensile-testing machine. The strain rate was $1 \times 10^{-3} / \mathrm{s}$ up to $\varepsilon=0.2 \%$ and thereafter $1.3 \times 10^{-2} / \mathrm{s}$ until the specimen broke. The grain size was determined by sectioning method, excluding twin boundaries, and the grain size dependence of $H V, \sigma_{0.2}$ and $\sigma_{\mathrm{B}}$ was determined. The value interpolated into $30 \mu \mathrm{m}$ grain size was taken as the characteristic values of the properties in each steel.

The measurement of the stress-strain curve and observation of the dislocation structure were made with specimens having the grain size from 30 to $40 \mu \mathrm{m}$. Tensile tests were performed at a strain rate of $6.7 \times 10^{-3} / \mathrm{s}$. The deformation sub-structure was observed with a transmission electron microscope operated at $200 \mathrm{KV}$ for materials deformed to 5, 20 and $30 \%$ tensile strains. The cell size was determined by counting the number of cells existing in 3 to 5 areas of $40 \mathrm{~mm}$ square each as observed at a magnification of $\times 15000$. An example of cell structure is shown in Fig. 2. Triple points of the cell are indicated. The cell boundary is drawn by connecting the 
triple points and the cell size is determined.

\section{Experimental Results}

\subsection{Effect of Alloying Elements on Hardness and Tensile Properties}

Figure 3 shows some examples of the relation of $H V$, $\sigma_{0.2}$ and $\sigma_{\mathrm{B}}$ to the grain size in the alloys A9, A1 and A11. Hardness $(H V), \sigma_{0.2}$ and $\sigma_{B}$ are smaller for the larger grain size. Values of $H V, \sigma_{0.2}$ and $\sigma_{\mathrm{B}}$ interpolated to the grain size of $30 \mu \mathrm{m}$ are taken to be their characteristic values.

The effect of alloying elements on $H V$ is shown in Fig. 4. As $\mathrm{C}$ and $\mathrm{N}$ (interstitial solutes), $\mathrm{Si}, \mathrm{Cr}$ and $\mathrm{Mo}$ (substitutional solutes and ferrite formers) are added, $H V$ increases. The effect of $\mathrm{C}$ and $\mathrm{N}$ is greater than that of $\mathrm{Si}, \mathrm{Cr}$ and $\mathrm{Mo}$. On the other hand, as $\mathrm{Ni}$ and $\mathrm{Cu}$ (substitutional solutes and austenite formers) are added, $H V$ decreases. $\mathrm{Mn}$, an austenite former, changes $H V$
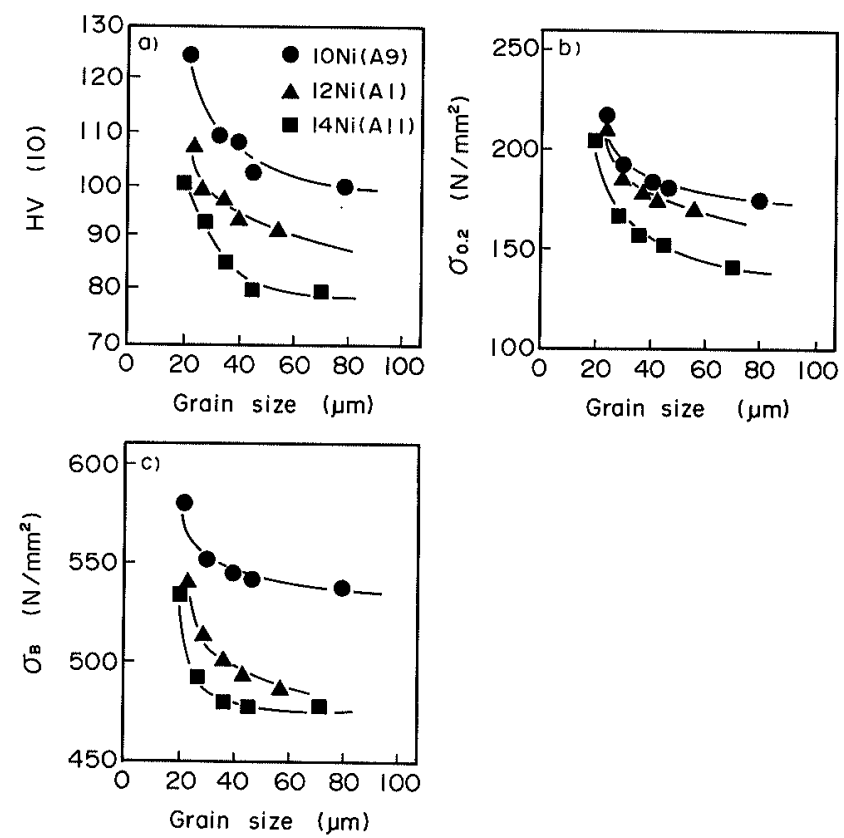

Fig. 3. Dependence of a) hardness $(H V(10))$, b) $0.2 \%$ proof stress $\left(\sigma_{0.2}\right)$ and c) tensile stress $\left(\sigma_{B}\right)$ on grain size in $10 \% \mathrm{Ni}$ steel (A9), $12 \% \mathrm{Ni}$ steel (Al) and $14 \% \mathrm{Ni}$ steel (A11).

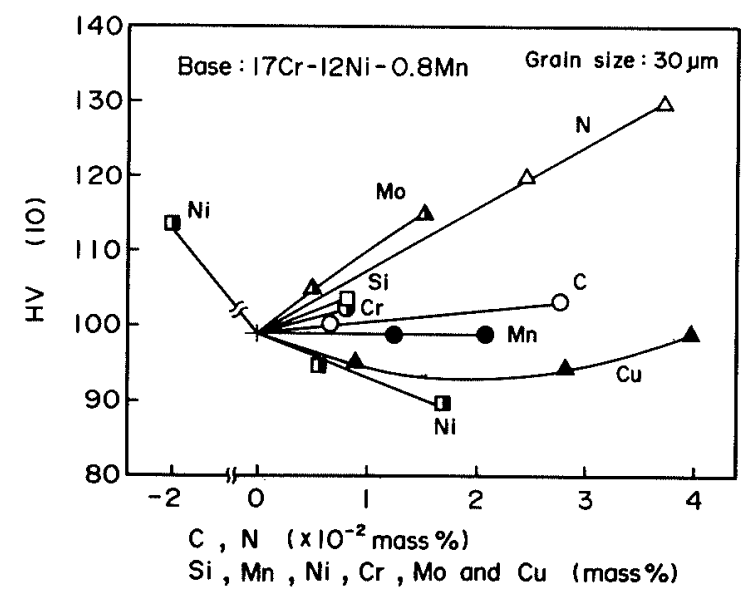

Fig. 4. Effect of alloying elements on hardness. little.

The effect of alloying elements on $\sigma_{0.2}$ is shown in Fig. 5. Similarly to the hardness, $\sigma_{0.2}$ is increased by the addition of $\mathrm{C}, \mathrm{N}, \mathrm{Si}, \mathrm{Cr}$ and $\mathrm{Mo}$, and decreased by Ni, $\mathrm{Cu}$ and $\mathrm{Mn}$. The effect of alloying elements on $\sigma_{\mathrm{B}}$ is shown in Fig. 6. Again $\sigma_{\mathrm{B}}$ is increased by $\mathrm{C}, \mathrm{N}, \mathrm{Si}, \mathrm{Cr}$ and $\mathrm{Mo}$, and decreased by $\mathrm{Ni}, \mathrm{Cu}$ and $\mathrm{Mn}$.

The above results are summarized as follows: In order to soften the austenitic stainless steel, it is effective to lower the contents of $\mathrm{C}, \mathrm{Si}, \mathrm{N}, \mathrm{Cr}$ and $\mathrm{Mo}$ and to increase the $\mathrm{Ni}, \mathrm{Cu}$ and $\mathrm{Mn}$ contents.

The relation between $H V, \sigma_{0.2}$ and $\sigma_{\mathrm{B}}$ and chemical compositions was formulated based on the results of Figs. 3 to 5 , by the multiple regression analysis. Hardness $(H V), \sigma_{0.2}$ and $\sigma_{\mathrm{B}}$ are expressed with the chemical composition with good accuracy by Eqs. (1) to (3). These equations are applicable for the alloys with the $\mathrm{Ni}$ contents 12 mass $\%$ and above, and also for those with $\mathrm{Cu}$ contents 2 mass \% and less. This is because that the deformation-induced Martensite forms during tensile deformation in steels with $\mathrm{Ni}$ below 12 mass \%, and $H V$, $\sigma_{0.2}$ and $\sigma_{\mathrm{B}}$ and saturated in steels with $\mathrm{Cu}$ above 2 mass $\%$.

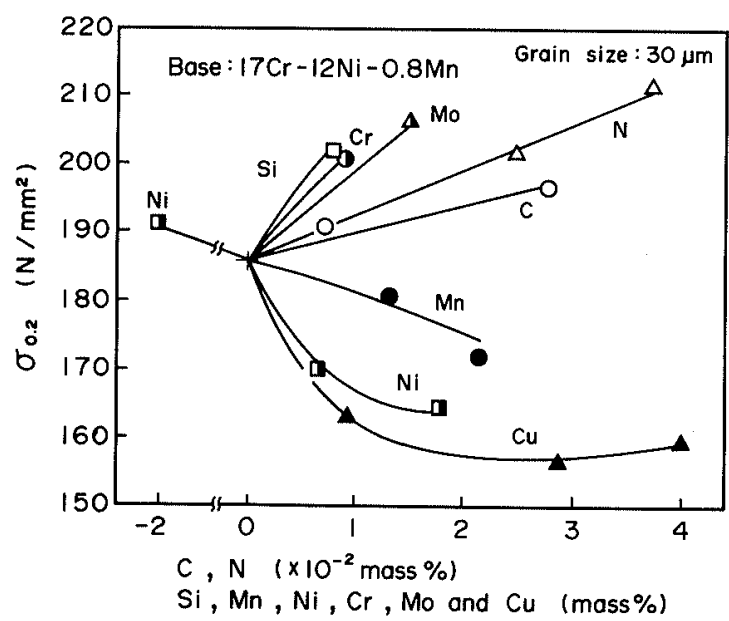

Fig. 5. Effect of alloying elements on $0.2 \%$ proof stress.

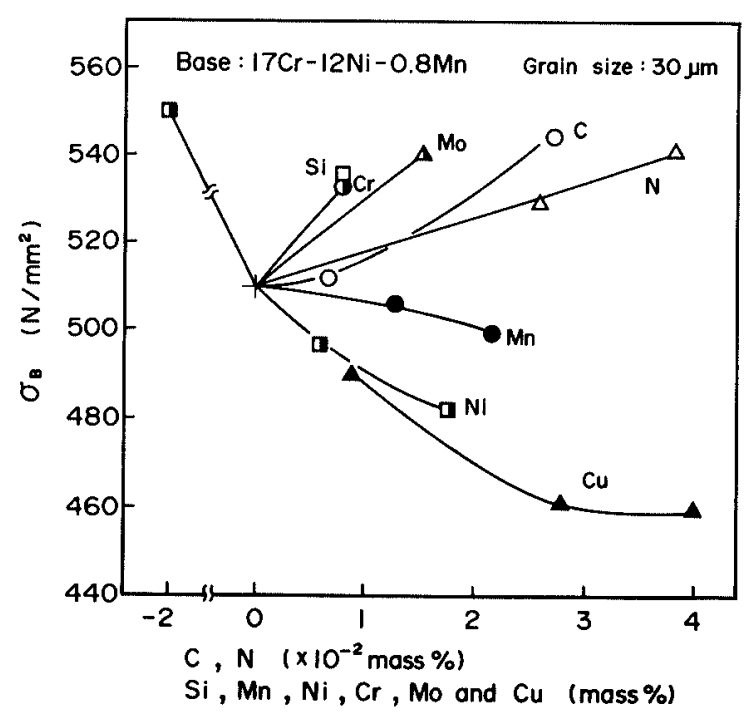

Fig. 6. Effect of alloying elements on tensile strength. 


$$
\begin{aligned}
H V(10)= & 8.7 \times 10 \mathrm{C}+7.9 \times 10^{2} \mathrm{~N}+2.0 \mathrm{Si}+2.7 \mathrm{Cr} \\
& +1.0 \times 10 \mathrm{Mo}-6.7 \mathrm{Ni}-2.6 \mathrm{Cu}+1.3 \times 10^{2}
\end{aligned}
$$

(Multiple correlation coefficient: 0.91 )

$$
\begin{aligned}
\sigma_{0.2}\left(\mathrm{~N} / \mathrm{mm}^{2}\right)= & 3.5 \times 10^{2} \mathrm{C}+6.5 \times 10^{2} \mathrm{~N}+2.0 \times 10 \mathrm{Si} \\
& +2.0 \times 10 \mathrm{Cr}+7.3 \mathrm{Mo}-0.3 \mathrm{Mn} \\
& -4.2 \mathrm{Ni}-5.6 \mathrm{Cu}-1.1 \times 10^{2}
\end{aligned}
$$

(Multiple correlation coefficient: 0.94)

$$
\begin{aligned}
\sigma_{B}\left(\mathrm{~N} / \mathrm{mm}^{2}\right)= & 1.1 \times 10^{3} \mathrm{C}+9.8 \times 10^{2} \mathrm{~N}+4.9 \mathrm{Si} \\
& +1.3 \times 10 \mathrm{Cr}+1.5 \times 10 \mathrm{Mo}-0.3 \mathrm{Mn} \\
& -1.8 \times 10 \mathrm{Ni}-1.4 \times 10 \mathrm{Cu}+5.0 \times 10^{2}
\end{aligned}
$$

(Multiple correlation coefficient: 0.95 )

(Applicable to 12 mass $\% \leqq \mathrm{Ni}$, and $\mathrm{Cu} \leqq 2.0$ mass $\%$ )

\subsection{Effect of Alloying Elements on the Flow Stress}

The stress-strain curves of Al (base steel), A3 (0.03\% C), A5 (0.04\% N), A6 (0.8\% Si), A $12(17.8 \% \mathrm{Cr}), \mathrm{A} 14$ $(1.5 \% \mathrm{Mo}), \mathrm{A} 8(3 \% \mathrm{Mn}), \mathrm{A} 11(14 \% \mathrm{Ni})$ and $\mathrm{A} 17(4 \%$ $\mathrm{Cu}$ ) are shown in Figs. 7a) to 7e). As shown in Fig. 7a), $\mathrm{N}$ increases the flow stress in the whole strain region (A5), while $\mathrm{C}$ increases the flow stress in high strain region (A3). Slight increase in the flow stress is observed in steels added with $\mathrm{Cr}$ and Mo, A12 and A14 in Fig. 7b), and significant increase in the Si-added steel (A6) especially in the high strain region. Effects of $\mathrm{Mn}, \mathrm{Ni}$ and $\mathrm{Cu}$ are shown in Fig. 7c). The flow stress decreases by the

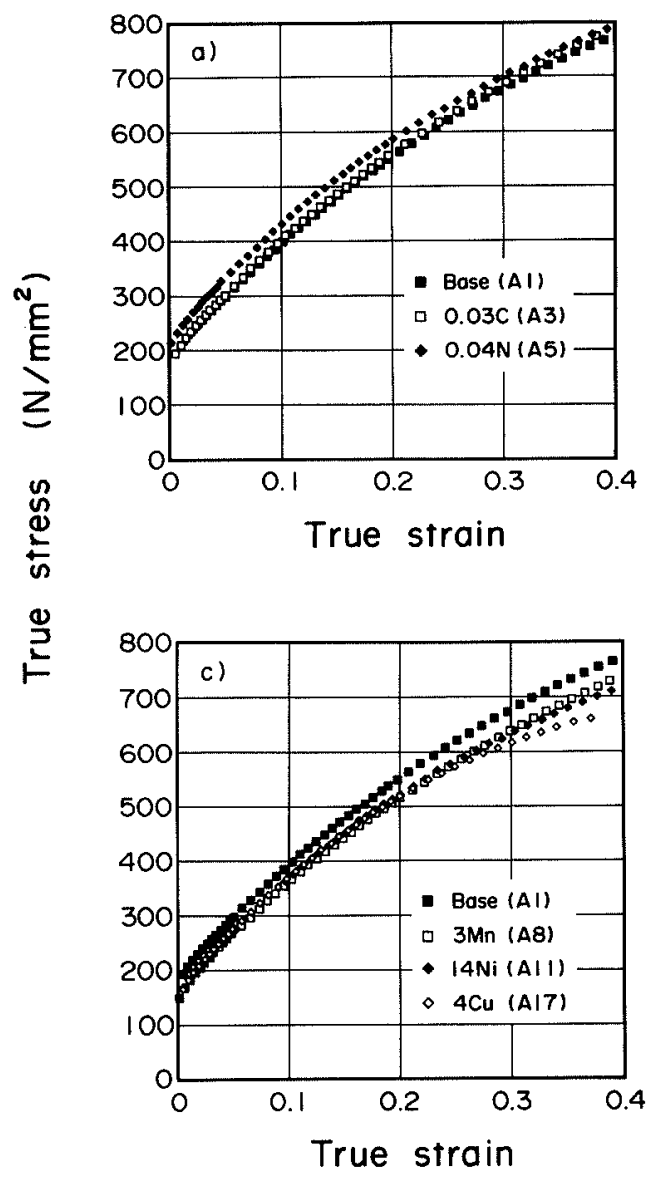

addition of these elements. The decreases in the $\mathrm{Ni}$ and $\mathrm{Cu}$ added steels are appreciable in the high strain region $(\varepsilon \geqq 0.3)$.

\subsection{Effect of Alloying Elements on Dislocation Struc- tures}

The dislocation structure of each steel after $20 \%$ tensile strain $(\varepsilon=0.18)$, except for $\mathrm{A} 12(17.8 \% \mathrm{Cr})$ and $\mathrm{A} 14$ $(1.5 \% \mathrm{Mo})$ in which only slight increase is observed in the flow stress, is shown in Fig. 8. The base steel as well as other steels added with $\mathrm{C}, \mathrm{Si}, \mathrm{Mn}, \mathrm{Ni}$ and $\mathrm{Cu}$ show cell structures. In A5 $(0.04 \% \mathrm{~N})$, the dislocation structure is ill-developed cell structure and the development of cell structure is restrained. The cell size after tensile strains of $20 \%(\varepsilon=0.18)$ and $30 \%(\varepsilon=0.26)$ is shown in Fig. 9. The range of error in Fig. 9 shows the dispersion of the values obtained from 3 to 5 areas in $40 \mathrm{~mm}$ square. It depends on the kind of alloying elements; after $20 \%$ strain, the cells size in the $0.03 \% \mathrm{C}$ and $0.8 \% \mathrm{Si}$ steels are smaller than that in the base steel. The cell size in the $3 \% \mathrm{Mn}$ steel is slightly larger and those in the $14 \%$ $\mathrm{Ni}$ and $4 \% \mathrm{Cu}$ steels are definitely lareger than that in the base steel. The cell size becomes smaller as the strain increases in all steels, and consequently the variation of cell size with alloying is hardly recognized after $30 \%$ tensile strain. Figure 10 shows the dislocation structures in alloys after $5 \%$ tensile strain. The base steel and A8 $(3 \% \mathrm{Mn})$ show cell structures. However, A6 $(0.8 \% \mathrm{Si})$ which exhibits a cell structure after $20 \%$ tensile strain (Fig. 8) shows a planner type of dislocation structure, similarly to A5 $(0.04 \% \mathrm{~N})$.

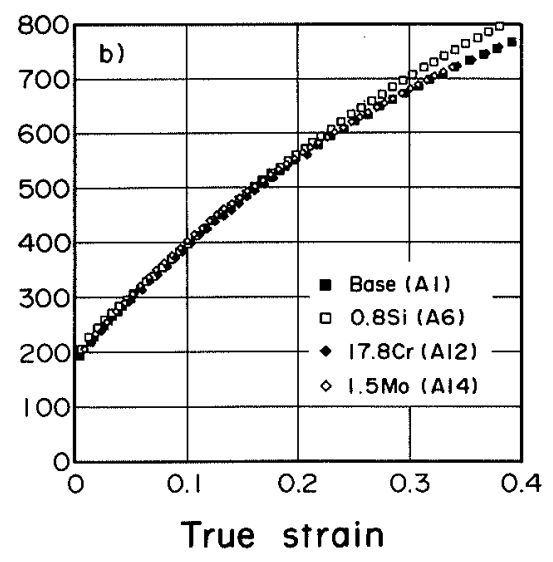

Fig. 7.

True stress-true strain curves of steels investigated. 


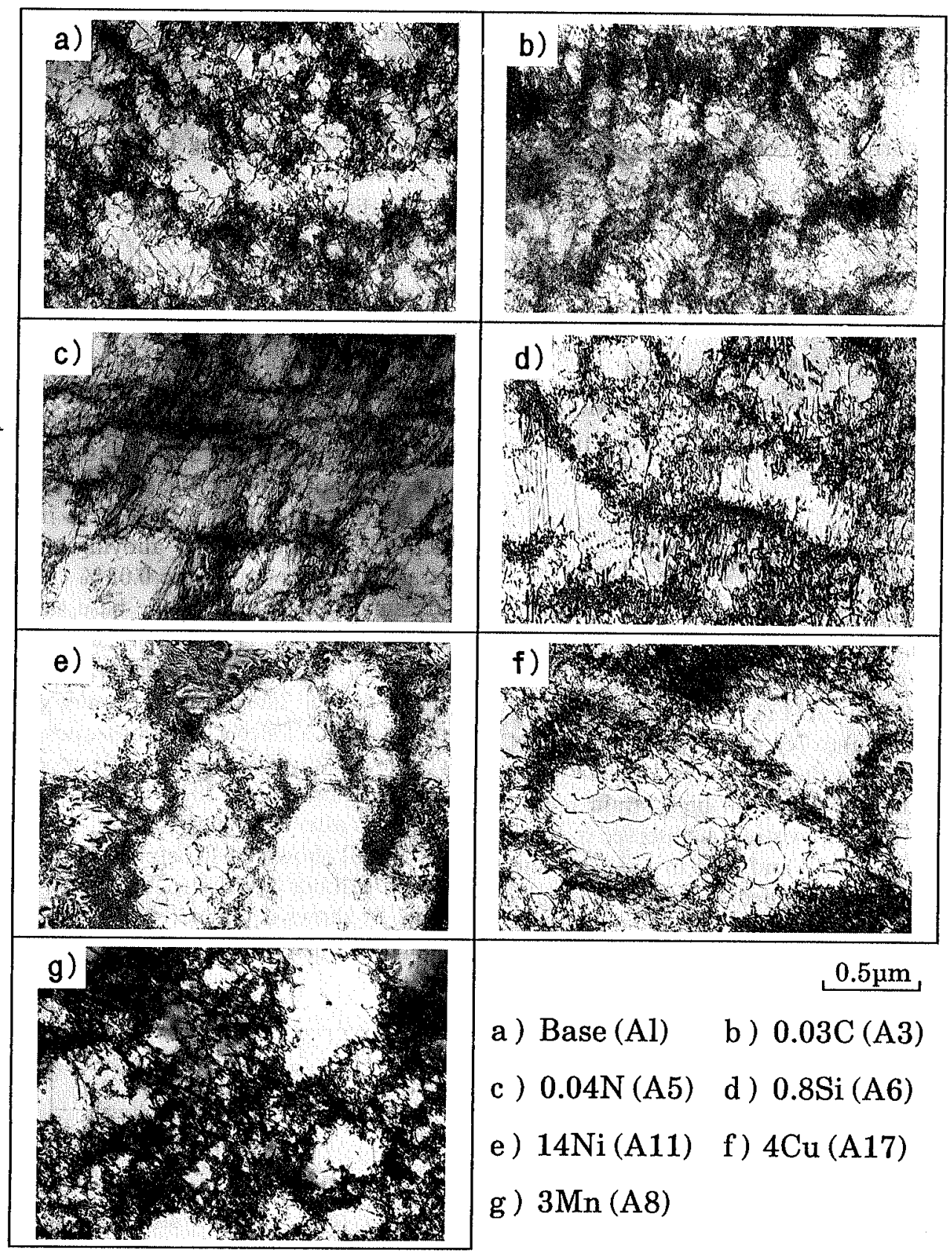

Fig. 8. Dislocation structure after $20 \%$ tensile strain $(\varepsilon=0.18)$.

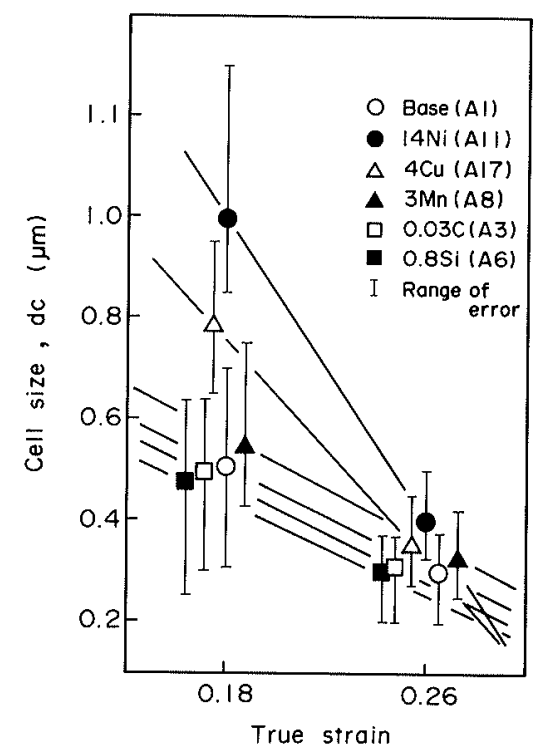

Fig. 9.

Change in cell size in steels after tensile strains of $20 \%$ and $30 \%$. 


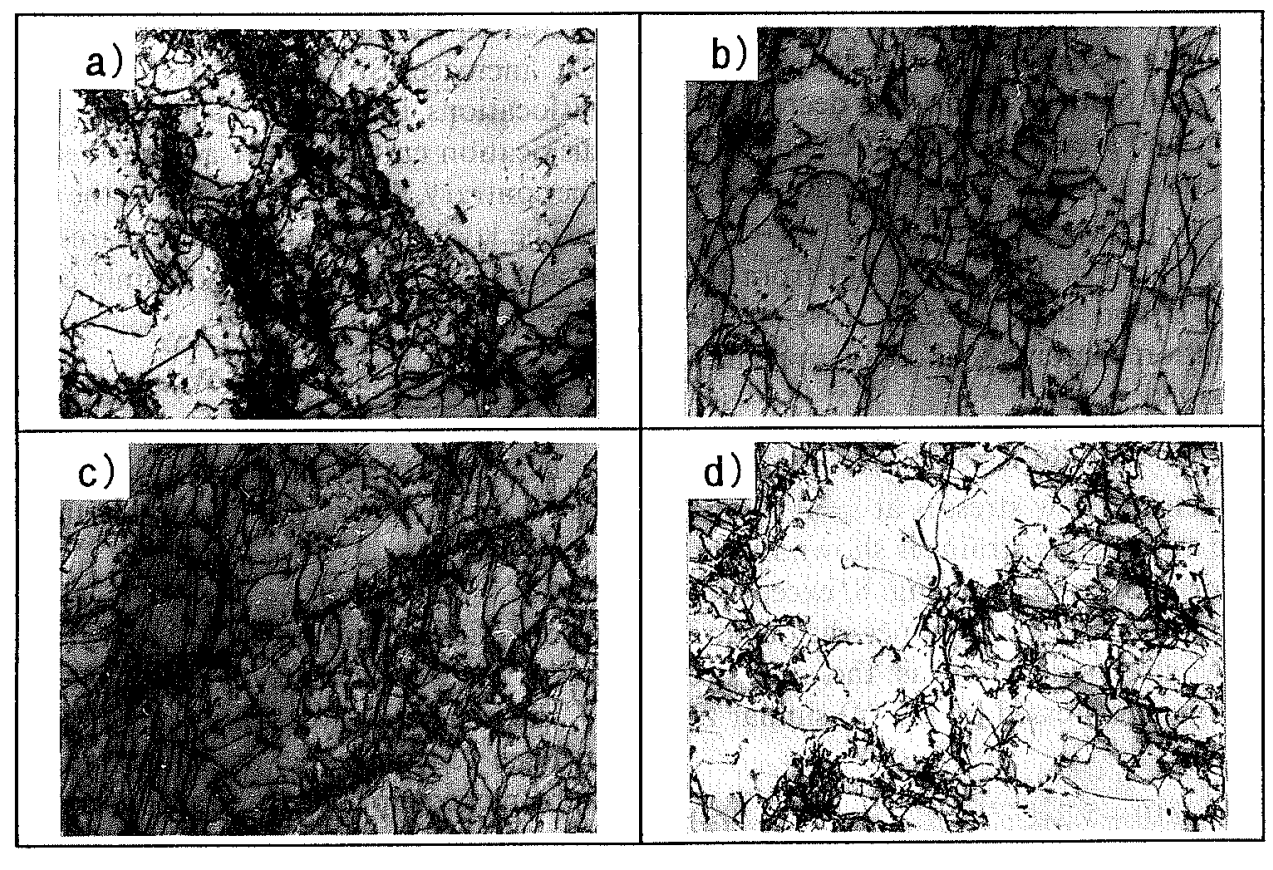
a) Base (Al)
b ) $0.8 \mathrm{Si}(\mathrm{A} 6)$
c ) $0.04 \mathrm{~N}(\mathrm{~A} 5)$
d ) $3 \mathrm{Mn}(\mathrm{A} 8)$

Fig. 10. Dislocation structure after $5 \%$ tensile strain $(\varepsilon=0.05)$.

\section{Discussions}

\subsection{Change in the Stacking Fault Energy as the Causes of Solution Hardening}

The lattice distortion due to dissolved alloying elements is one of the important causes of the solid solution hardening. In Fig. 11 is shown the increase in $0.2 \%$ proof stress per 1 at $\%$ of solutes reported in the present paper and by Dyson et al., ${ }^{7)}$ against the rate of lattice parameter change due to solutes reported by Dyson et al. Both results generally agree with each other. There is no doubt in saying that the lattice distortion is the predominant cause of the solution hardening. Close inspection, however, reveals the deviation of some results from this rule. For $\mathrm{Si}, \mathrm{Cr}, \mathrm{Ni}, \mathrm{Mn}$ and $\mathrm{Cu}$ the rate of lattice parameter change is less than $2 \%$ per $1 \mathrm{at} \%$ of solutes, even almost naught for $\mathrm{Si}, \mathrm{Ni}$ and $\mathrm{Mn}$. Still, $\mathrm{Si}$ and $\mathrm{Cr}$ cause hardening, and $\mathrm{Ni}, \mathrm{Mn}$ and $\mathrm{Cu}$ cause softening. These effects are small but clearly beyond the experimental accuracy, and the softening is effective in decreasing the springback in bending. There are some differences in the effect of $\mathrm{Si}, \mathrm{Cr}, \mathrm{Ni}, \mathrm{Mn}$ and $\mathrm{Cu}$ between the present results and the results of Dyson et al. Dyson et al. used the steel containing about $0.08 \% \mathrm{C}, 1.0 \%$ $\mathrm{Mn}, 0.3 \% \mathrm{Si}$ and $0.02 \% \mathrm{~N}$ as the base steel. The concentrations of $\mathrm{C}$ and $\mathrm{N}$ are higher by one order magnitude than those in this present research. Hence there is a possibility that the change in $\mathrm{C}$ and $\mathrm{N}$ cancel the effect of $\mathrm{Si}, \mathrm{Cr}, \mathrm{Ni}, \mathrm{Mn}$ and $\mathrm{Cu}$ on $0.2 \%$ proof stress.

These hardening and softening effects are explained in terms of SFE: It has been shown theoretically that the increase in SFE decreases the width of extended dislocations and hence the climbing, cross-slip and

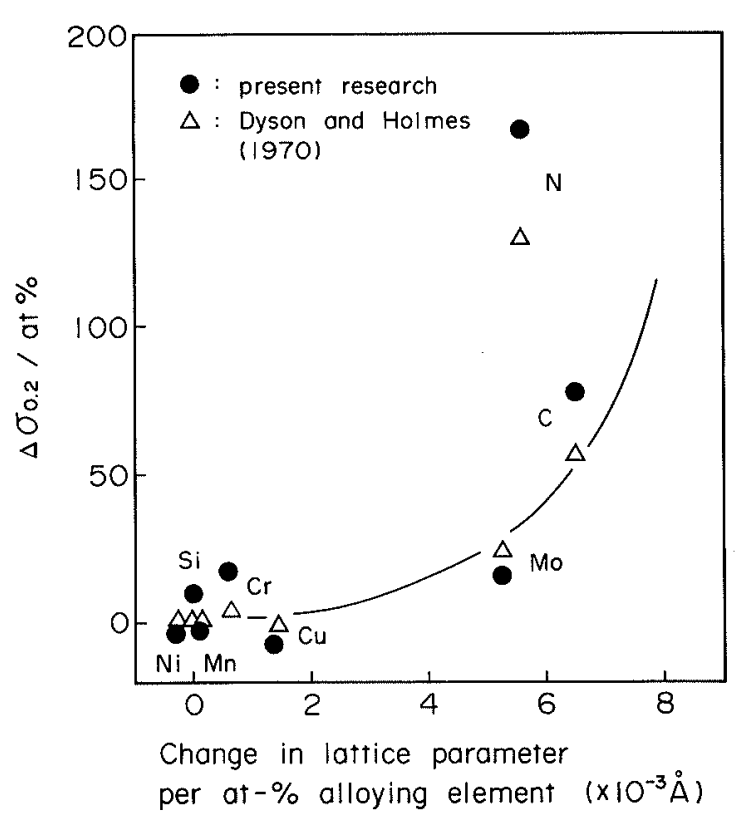

Fig. 11. Relation between the change in $0.2 \%$ proof stress per 1 at $\%$ of alloying element $\left(\Delta \sigma_{0.2}\right)$ and the change in lattice parameter per 1 at $\%$ of alloying element.

mutual cutting of dislocations become easier. Thus, the addition of a solute increasing SFE is expected to decrease the yield and flow stresses. If SFE is decreased the opposite will be observed. Silicon is considered to decrease SFE in austenitic stainless steels, ${ }^{9}$ and the hardening is observed as expect. As for $\mathrm{Cr}$, Dulieu and Nutting ${ }^{9)}$ reported an increase in SFE, while Breedis ${ }^{12)}$ reported an decrease. According to the present consideration, our result, i.e., $\mathrm{Cr}$ causing hardening, supports the 
Breedis' result. $\mathrm{Ni}$ and $\mathrm{Cu}$ are reported to increase $\mathrm{SFE},{ }^{9)}$ and they cause softening as expect. As for the effect of Mn on SFE, Dulieu and Nutting reported a decrease in SFE, while Schramm and Reed ${ }^{10)}$ reported an increase in commercial grade austenitic stainless steel. The present investigation shows that the addition of $\mathrm{Mn}$ increases the cell size (Fig. 9). This increase may result from the slight increase in SFE and hence the increase in the probability of dislocation climbing and cross-slip. Thus, the softening is observed.

\subsection{Effect of Cell Size on Flow Stress}

The relation between the flow stresses at $\varepsilon=0.18$ and 0.26 and the cell size at the same strains is shown in Fig. 12. These data are for alloys shown in Fig. 8, except for A5 $(0.04 \% \mathrm{~N})$ which exhibits the planner dislocation structures. The flow stress increases as the cell size decreases. The relation is expressed by Eq. (4) similar to the Hall-Petch relation. ${ }^{15,16)}$

$$
\sigma=310+5.2 d_{c}^{-1 / 2},
$$

where, $\sigma:$ the flow stress in $\mathrm{N} / \mathrm{mm}^{2}$, and

$d_{c}$ : the cell size in $\mathrm{mm}$.

It has been reported that the relation similar to the Hall-Petch relation holds between the fiow stress and the cell size for $\alpha \mathrm{Fe}^{17)}$ and $\mathrm{Al}$ polycrystalline specimens. ${ }^{18)}$ In the relation between the flow stress and the cell size, the coefficient of $d_{c}^{-1 / 2}$ represents the extent to which the dislocation movement is hindered by the cell wall. The coefficient of $d_{c}^{-1 / 2}$ in this research is $5.2 \mathrm{~N} \cdot \mathrm{mm}^{-3 / 2}$, while the coefficient in the relation between the $0.2 \%$ proof stress and grain size for $16 \mathrm{Cr}-10 \mathrm{Ni}$ austenitic stainless steel is about $12 \mathrm{~N} \cdot \mathrm{mm}^{-3 / 2} \cdot{ }^{19)}$ The coefficient in this research is smaller. This result suggests that the grain boundary contributes to hinders the dislocation movement more than the cell wall.

Araki et al. ${ }^{20)}$ have been reported that the cell size in ausformed steels depends on the kind of alloying elements. We have found, as shown in Figs. 8 and 9, that the cell size is increased by the addition of $\mathrm{Ni}$, $\mathrm{Mn}$ and $\mathrm{Cu}$ which increase SFE, while it is slightly

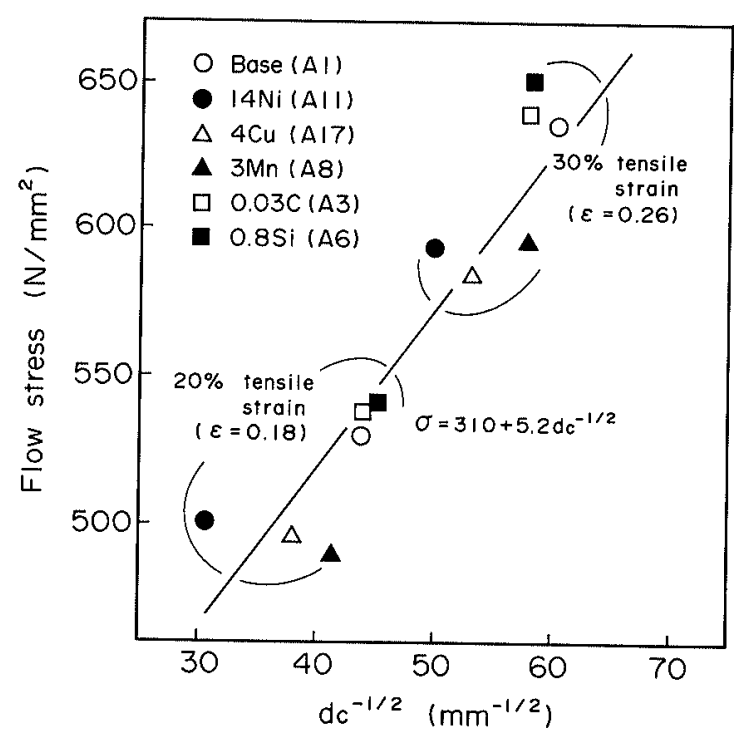

Fig. 12. Relation between the flow stress and cell size. decreased by Si which decreases SFE. Nickel, Mn and $\mathrm{Cu}$ increase SFE, and the width of the extended dislocations is reduced. The reduced width makes the dislocation cutting easier and the cell size increases. On the contrary, Si reduced SFE, and the cell size decreases.

The level of flow stress is increased by the addition of $\mathrm{C}$ and $\mathrm{N}$. The hardening is mainly caused by the lattice strain.

\subsection{Relation between Work Hardening Rate and Stacking Fault Energy}

The flow stress of polycrystals at a given temperature and a strain rate is expressed ${ }^{21)}$ with Eq. (5)

$$
\sigma=K \varepsilon^{n},
$$

where $\sigma$ is the true stress, $K$ a constant, $\varepsilon$ the true strain and $n$ the work hardening exponent.

The change in work hardening rate, $d \sigma / d \varepsilon$, is shown in Figs. 13a) and 13c) as a function of $\varepsilon$. Three points were picked up with a strain interval of 0.008 on the true stress-true stain curve, and $\sigma$ was expressed as a secondary function of $\varepsilon$ in the range with the Lagrange interpolation method. The value of $d \sigma / d \varepsilon$ was calculated at the strain for the middle of the three points. The same procedure was repeated up to the high strain region. None of steels in the present experiment exhibits linear hardening in the whole range of strain, but the work hardening rate decreases steeply in the high strain region $(\varepsilon \geqq 0.1)$.

The work hardening rates for $\varepsilon \geqq 0.1$ are shown in Figs. 14a) and 14b). It increases remarkably by the addition of $\mathrm{Si}$ and slightly increases by $\mathrm{C}$ in the high strain region $(\varepsilon \geqq 0.2)$. On the other hand, it decreases by $N$. It also decreases by the addition of $\mathrm{Mn}, \mathrm{Ni}$ and $\mathrm{Cu}$; especially the effect of $\mathrm{Cu}$ and $\mathrm{Ni}$ is remarkable. The change in the work hardening rates by alloying will be explained in terms of SFE in the following sections.

The relation between SFE and cell size is already discussed. The work hardening rate after 20 and $30 \%$ tensile strains is shown in Fig. 15 against the cell size which depends on the SFE. The work hardening rate at $20 \%$ tensile strain apparently depends on the cell size. But this dependence is superficial. Since the work handening rate is the stress per unit strain, the cell size does not affect to the work hardening rate directly. The variation of work hardening rate should be attributed to the change in SFE by the alloying. When $\mathrm{Ni}, \mathrm{Mn}$ and $\mathrm{Cu}$ are added, SFE is increased and, as the result, the work hardening rate decreases as already mentioned. Contrarily, the cross-slip tends to be restrained by $\mathrm{Si}$ and $\mathrm{C}$, therefore the work hardening rate is increased.

The work hardening rate at $30 \%$ tensile strain more clearly shows the effect of SFE. Since all the alloys have almost the same cell size at this tensile strain, the variation of work hardening rate should be due to the variation of SFE. Tensile strain of $30 \%$ is in the range of stage III of the work hardening, which is a result of dynamic recovery ${ }^{22)}$ caused by cross-slip. In an alloy with high SFE the cross-slip is easier and hence stage III commences at a smaller strain than in an alloy with low SFE. Thus, in the high SFE alloys, i.e., A11, A17 and A8, stage III 

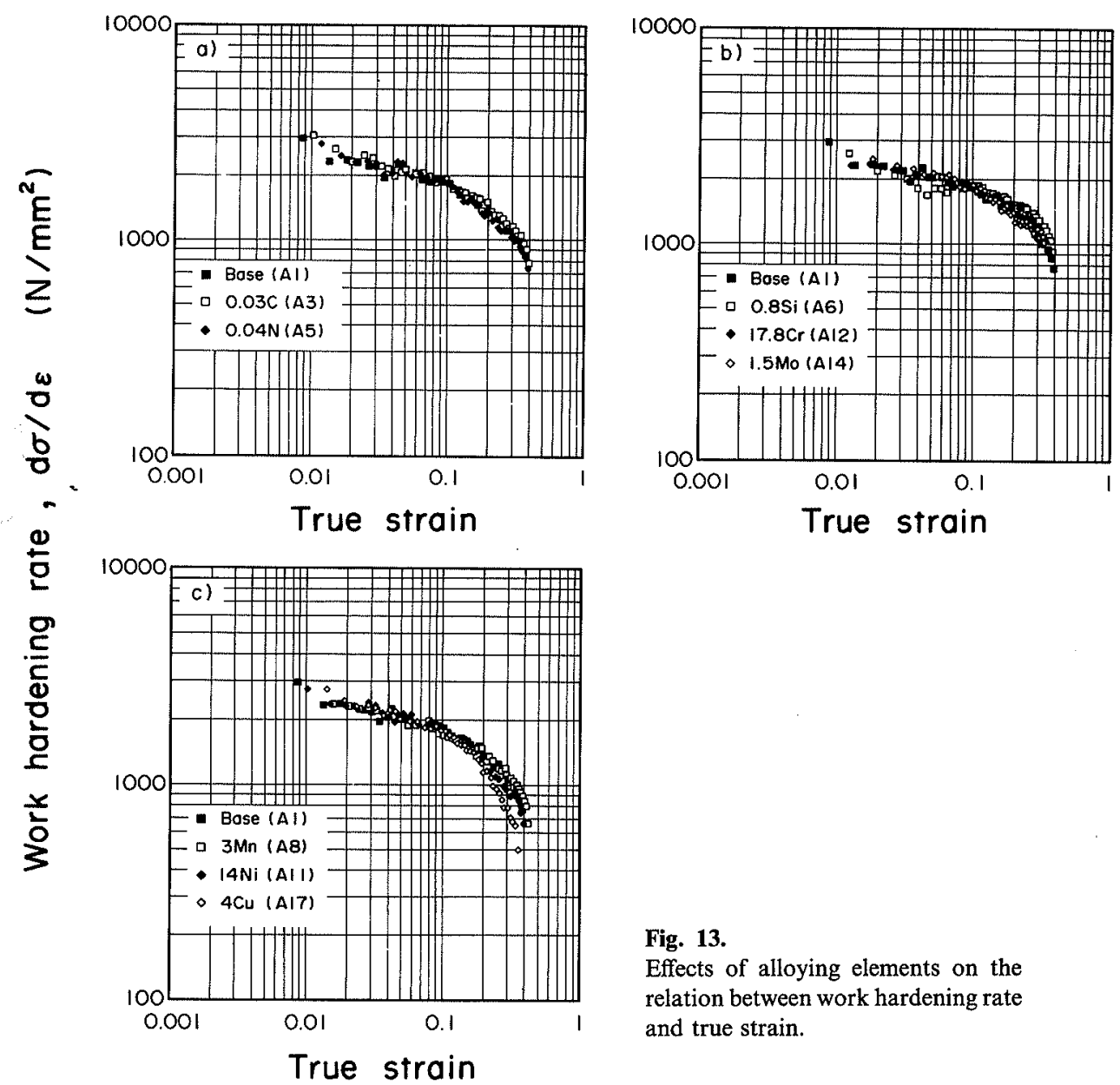

Fig. 13.

Effects of alloying elements on the relation between work hardening rate and true strain.
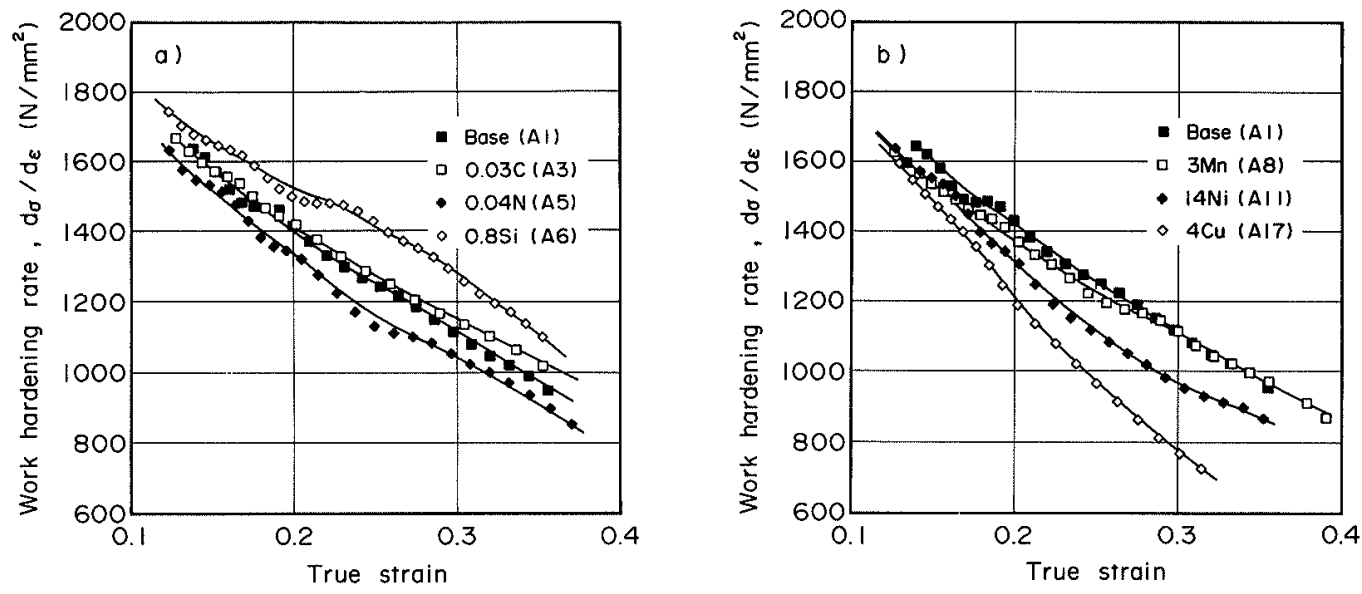

Fig. 14. Change in work hardening rate according to the increase in true strain above 0.1 .

commences earlier than in the low SFE alloy, i.e., A6, and consequently more stage III deformation has occurred before $30 \%$ tensile strain is achieved. The more deformation in stage III causes more dynamic recovery and hence the work hardening rate decreases.

Thus, the work hardening rate is determined by easinesss of the cross-slip governed by SFE. The work hardening rate until necking is a significant index in spinning, drawing and bulging. Its reduction is preferable to formability, and can be achieved by lowering the $\mathrm{Si}$ and $\mathrm{C}$ content and increasing $\mathrm{Mn}, \mathrm{Ni}$ and $\mathrm{Cu}$.

Nitrogen ${ }^{9,10)}$ reduces SFE of austenitic stainless steels as $\mathrm{Si}$ does. The work hardening rate is expected to be increased by $\mathrm{N}$ as well as by $\mathrm{Si}$. However, the work hardening rate tends to decrease rather than to increase. As described before, the cell structure is not formed by the addition of $\mathrm{N}$, while $\mathrm{Si}$ forms the cell structure. This is likely to be the cause of the difference between $\mathrm{Si}$ and $\mathrm{N}$.

\section{Conclusions}

The effects of various alloying elements on the mechanical properties of stable austenitic stainless steel have been investigated. The solution hardening and work hardening rate have been discussed in terms of the dislocation structures. 


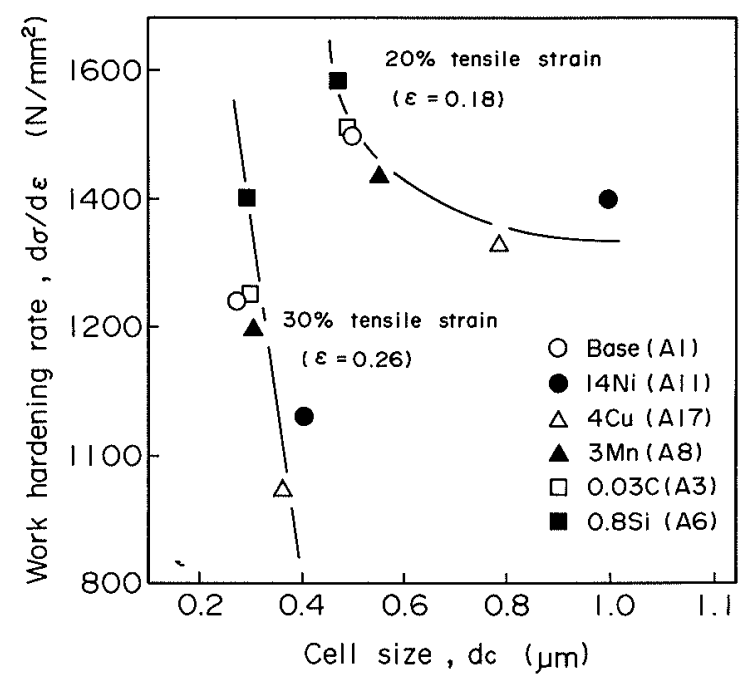

Fig. 15. Relation between work hardening rate at $20 \%$ tensile strain $(\varepsilon=0.18)$ and $30 \%$ tensile strain $(\varepsilon=0.26)$ and cell size.

(1) Experimental equations to give the hardness $(H V), 0.2 \%$ proof stress $\left(\sigma_{0.2}\right)$ and tensile strength $\left(\sigma_{B}\right)$ as functions of the chemical composition are proposed.

(2) Reduction of $\mathrm{C}, \mathrm{N}, \mathrm{Si}, \mathrm{Cr}$ and $\mathrm{Mo}$ and addition of $\mathrm{Ni}, \mathrm{Cu}$ and $\mathrm{Mn}$ are effective to decrease the hardness, $0.2 \%$ proof stress and tensile strength.

(3) $\mathrm{C}, \mathrm{N}$ and $\mathrm{Mo}$ induce lattice strains to increase $\sigma_{0.2}$. Hence, the reduction of these elements results in softening. $\mathrm{Ni}, \mathrm{Mn}$ and $\mathrm{Cu}$, which increase stacking fault energy, decrease $\sigma_{0.2}$, through reduction of the width of extended dislocations. Although these elements cause slight lattice strains, the softening exceeds the hardening due to the lattice strains. Addition of $\mathrm{Si}$, which reduces SFE, increase $\sigma_{0.2}$.

(4) The dislocation structures are essentially cellstructures, except for $\mathrm{N}$-added steels. The cell size is varied by alloying elements through the change of SFE.
(5) The work hardening rate is reduced by $\mathrm{Ni}, \mathrm{Cu}$ and $\mathrm{Mn}$. These elements have been reported to increase SFE and hence are considered to activate cross-slip. On the other hand, a SFE-reducing element, $\mathrm{Si}$, increases the work hardening rate. The addition of $\mathrm{N}$, another SFE-reducing element, however, decreases work hardening rate. This effect may result from the difficulty in forming the cell-structure in the $\mathrm{N}$-added steel in contrast to the Si-added steel.

\section{REFERENCES}

1) T. Angel: J. Iron Steel Inst., 177 (1954) 5, 165.

2) D. C. Ludwigson and J. A. Berger: J. Iron Steel Inst., 207 (1969), 413.

3) K. Hoshino: J. Jpn. Soc. Technol. Plast., 16 (1975), 993.

4) K. Hoshino: Tetsu-to-Hagané, 63 (1977), 659.

5) K. Nohara, H. Ono and N. Ohhashi: Tetsu-to-Hagané, 63 (1977), 772 .

6) K. J. Irvine, T. Gladman and F. B. Pickering: J. Iron Steel Inst., 207 (1969), 1017.

7) D. J. Dyson and B. Holmes: J. Iron Steel Inst., 208 (1970), 469.

8) I. Tamura: The Strength of Steels, The Nikkan Kogyo Press Co., Ltd., Tokyo, (1969), 10.

9) D. Dulieu and J. Nutting: J. Iron Steel Inst. Spec. Rep., 86 (1964), 140.

10) R. E. Schramm and R.P. Reed: Metall. Trans., 6A (1975), 1345.

11) R. Fawley, M. A. Quader and R. A. Dodd: Trans. Metall. Soc. AIME, 242 (1968), 771.

12) J. F. Breedis: Trans. AIME, 230 (1964), 1583

13) M. Ueki, T. Koyama, S. Sakai and M. Nakamura: Tetsu-toHagané, 71 (1985), 743.

14) K. J. Irvine, D. T. Llewellyn and F. B. Pickering: J. Iron Steel Inst., 199 (1961), 356.

15) E. O. Hall: Proc. Phys. Soc. (London), 64 (1951), 747.

16) N. J. Petch: J. Iron Steel Inst., 174 (1953) 5, 25.

17) G. Langford and M. Cohen: Metall. Trans., 1 (1970), 1478.

18) H. Fujita: Bull. Jpn. Inst. Met., 14 (1975), 837.

19) S. Takagi, S. Tanimoto, H. Tomimura and $Y$. Tokunaga: Tetsu-to-Hagané, 74 (1988), 1058.

20) T. Araki, T. Watanabe and H. Miyamoto: Toward Improved Ductility and Toughness, ed. by ISIJ, Tokyo, (1971), 173.

21) J. H. Hollomon: Trans. AIME, 162 (1945), 268

22) G. B. Gibbs: Mater. Sci. Eng., 4 (1969), 313. 